\title{
CONDITION OF MANGROVE FORESTS IN DOMPAK URBAN VILLAGE BUKIT BESTARI SUB-DISTRICT RIAU ISLAND PROVINCE
}

\author{
Andrean Nggara Imanuel ${ }^{*}$, Efriyeldi ${ }^{2}$, Syafruddin Nasution $^{2}$ \\ ${ }^{1}$ Student of the Faculty of Fisheries and Marine Universitas Riau, Pekanbaru \\ ${ }^{2}$ Lecturer at the Faculty of Fisheries and Marine Universitas Riau, Pekanbaru \\ *andrenggara@gmail.com
}

\begin{abstract}
This study was conducted in December 2019, which was located in Dompak Village, Bukit Bestari District, Tanjungpinang City, Riau Islands Province. The purpose of this study was to determine the species composition and condition of mangrove forests based on the value of density, canopy cover and the importance value index of mangroves. The survey method was used in this study, where the data collected was primary data. There are 10 types of mangroves including Avicennia lanata, Bruguiera gymnorrhiza, B. cylindrica, Rhizophora apiculata, R. stylosa, Nypa fruticans, Sonneratia alba, Xylocarpus granatum, Scyphiphora hydrophyllacea and Hibiscus tiliaceus. Mangrove density was in good condition with moderate to dense ranging from 1344.44-1555.56 ind/ha. Canopy cover was in good condition ranging from $61.49-68.47 \%$. The highest importance value index was $R$. apiculata with a value of $140.32 \%$ and the lowest was B. cylindrica with a value of $4.29 \%$.
\end{abstract}

Keywords: Dompak Village, Composition, Condition, Mangrove.

\section{PENDAHULUAN}

Kondisi hutan mangrove yang berada di Indonesia telah mengalami penurunan akibat dari pengaruh aktivitas manusia, seperti pembangunan daerah pesisir, perluasan pembangunan tambak, abarasi air laut, dan penebangan yang berlebihan. Kerusakan dan kehilangan ekosistem hutan mangrove yang terjadi dalam bentuk konversi lahan mangrove merupakan salah satu peristiwa yang sudah sering terjadi di kawasan pesisir. Konversi lahan yang terjadi di kawasan pesisir akan menyebabkan terjadinya penurunan luasan hutan mangrove. Salah satu kawasan yang telah mengalami penurunan luasan hutan mangrove terdapat pada kawasan pesisir Kelurahan Dompak Kecamatan Bukit Bestari Kota Tanjungpinang Provinsi Kepulauan Riau. Dompak merupakan pulau kecil yang memiliki potensi sumber daya mangrove yang cukup luas, dimana dari seluruh total ekosistem mangrove di Kota Tanjung pinang sebanyak $27,6 \%$ terdapat di Pulau Dompak (Husin et al., 2017). Akan tetapi kawasan ini telah dijadikan sebagai salah satu pusat pengembangan kota, sehingga menyebabkan terjadinya konversi lahan mangrove secara besar-besaran menjadi kawasan perkantoran, perumahan masyarakat, pembangunan jalan dan infrastruktur penunjang lainnya.

Penurunan luasan hutan mangrove yang terjadi dapat mempengaruhi komposisi spesies mangrove dan kondisi dari suatu ekosistem hutan mangrove itu sendiri. Bila suatu ekosistem hutan mangrove memiliki nilai kerapatan mangrove dan persentase tutupan kanopi mangrove yang tinggi maka kondisi hutan 
mangrove tersebut dalam kondisi yang baik.

Informasi mengenai status kondisi hutan mangrove yang berada di kawasan pesisir Kelurahan Dompak Kecamatan Bukit Bestari Kota Tanjungpinang Provinsi Kepulauan Riau masih belum banyak dijumpai dan perlu pembaharuan informasi mengenai kondisi hutan mangrove yang ada.

Tujuan dari penelitian ini adalah untuk mengetahui komposisi spesies mangrove yang ditemukan dan untuk mengetahui kondisi hutan mangrove berdasarkan nilai kerapatan, tutupan kanopi dan indeks nilai penting mangrove di kawasan pesisir Kelurahan Dompak Kecamatan Bukit Bestari Kota Tanjungpinang Provinsi Kepulauan Riau

\section{METODE PENELITIAN Waktu dan Tempat}

Penelitian ini dilaksanakan pada bulan Desember 2019 di kawasan hutan mangrove Kelurahan Dompak Kecamatan Bukit Bestari Kota Tanjung pinang Provinsi Kepulauan Riau (Gambar 1).

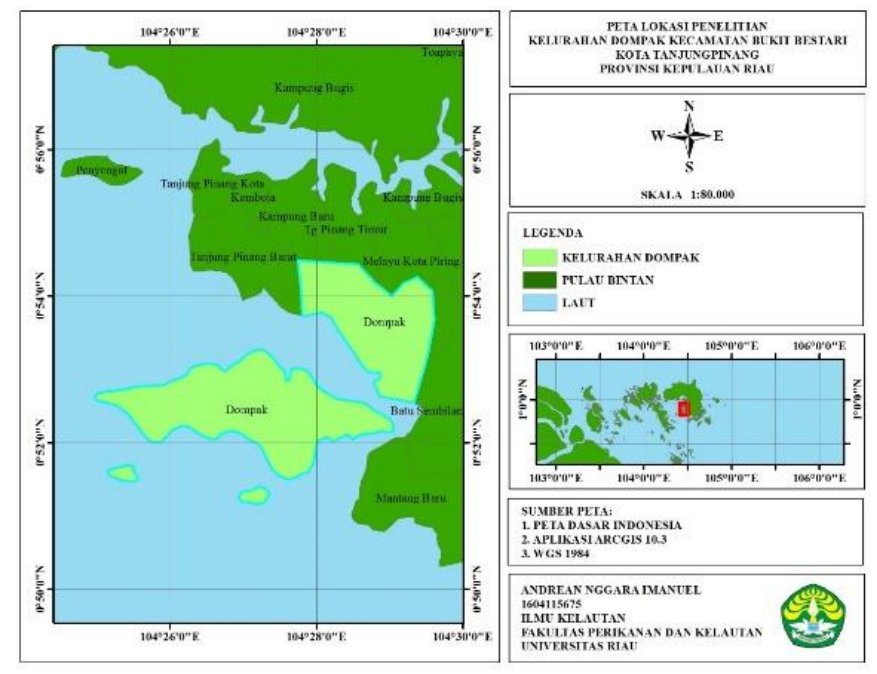

Gambar 1. Peta Lokasi Penelitian

\section{Metode Penelitian}

Metode yang digunakan dalam penelitian ini adalah metode survei, dimana data yang dikumpulkan adalah data primer yang meliputi data kerapatan, persentase tutupan kanopi dan indeks nilai penting mangrove serta data kualitas air dan fraksi sedimen yang selanjutnya akan disajikan pada tabel dan gambar secara deskriptif.

\section{Prosedur Penelitian}

Penentuan lokasi titik stasiun menggunakan teknik purposive sampling, yaitu pemilihan subjektif berdasarkan ciriciri karakteristik lapangan setelah dilakukan survei yaitu pengaruh aktivitas manusia. Stasiun I adalah kawasan mangrove yang berada dekat dengan permukiman masyarakat, stasiun II adalah kawasan mangrove yang berada dekat dengan pelabuhan kapal dan stasiun III adalah kawasan mangrove yang berada jauh dari permukiman masyarakat.

Masing-masing stasiun terdapat 3 transek garis lurus sepanjang 50 meter dari arah laut ke darat dengan posisi tegak lurus terhadap pantai dan memiliki jarak antar jalur transek 50 meter. Di setiap jalur transek terdapat 3 plot yang disusun secara zig-zag dengan ukuran 10x10 $\mathrm{m}^{2}$ untuk struktur komunitas mangrove kategori pohon. Kemudian setiap plot terdapat empat sub plot dengan ukuran $5 \times 5 \mathrm{~m}^{2}$ yang 
digunakan sebagai titik pengambilan foto kanopi mangrove (Gambar 2).

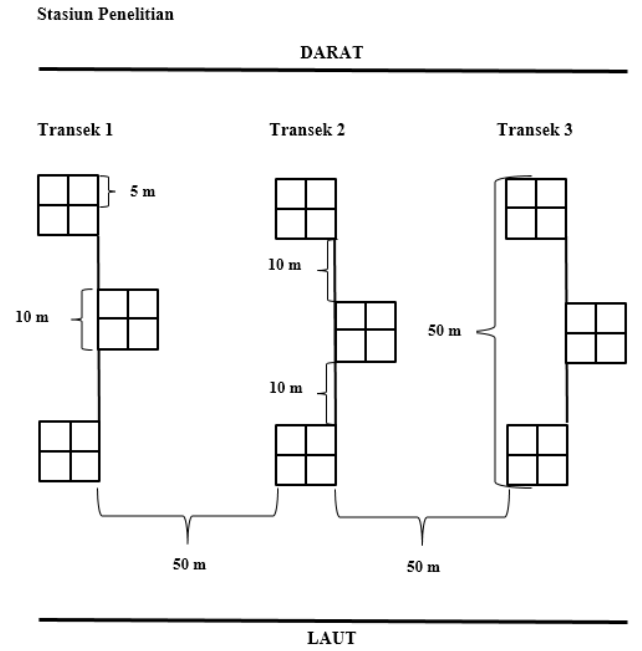

Gambar 2. Skema Letak Transek dan Plot Pengamatan Mangrove di Kelurahan Dompak

Pengukuran kualitas air dilakukan dengan cara in situ atau secara langsung di lokasi penelitian dan pengukuran dilakukan pada saat pasang di pagi hari. Masingmasing pengukuran kualitas air dilakukan tiga kali ulangan di satu titik lokasi penngambilan data. Hal ini bertujuan supaya data yang diperoleh bersifat lebih akurat.

Pengambilan sampel sedimen dilakukan untuk mengetahui tipe fraksi sedimen pada setiap stasiun dengan $3 \mathrm{kali}$ pengulangan pengambilan sampel lalu dicampur menjadi satu dan diambil menggunakan sekop kecil. Sampel diambil sebanyak \pm 500 gram kemudian sampel dimasukkan ke dalam kantong plastik dan diberi label sesuai lokasi pengambilan sampel lalu dimasukkan ke dalam ice box untuk selanjutnya dibawa ke Laboratorium Kimia Laut Jurusan Ilmu Kelautan Fakultas Perikanan dan Kelautan Universitas Riau untuk dianalisis.

Identifikasi jenis mangrove dilakukan dengan mengamati beberapa bagian dari morfologi tumbuhan mangrove seperti daun, bunga, buah, batang dan tipe akar untuk kemudian disesuaikan dengan buku identifikasi mangrove. Selain itu, dapat didokumentasikan dengan mengambil gambar pada bagian morfologi tumbuhan mangrove untuk dilakukan identifikasi lebih lanjut. Identifikasi jenis mangrove mengacu pada buku Panduan Pengenalan Mangrove di Indonesia (Noor et al., 2006). Data kerapatan mangrove diambil dengan metode line transect plot. Data diambil dalam 3 stasiun pengamatan. Setiap stasiun pengamatan terdapat 3 transek, setiap transek terdapat 3 plot, tiap plot memiliki ukuran $10 \times 10 \mathrm{~m}^{2}$ untuk kategori pohon (diameter batang setinggi dada lebih dari $4 \mathrm{~cm}$ ).

Cara pembuatan transek kuadrat untuk melakukan pengambilan data kerapatan mangrove dilakukan sebagai berikut (Gambar 2):

1. Transek ditarik dari garis pantai ke arah darat sepanjang 50 meter

2. Tiap transek terdapat 3 plot dengan jarak masing-masing plot 10 meter

3. Tiap plot memiliki ukuran $10 \times 10$ $\mathrm{m}^{2}$ untuk kategori pohon.

4. Data yang diambil adalah jumlah individu yang ditemukan dalam jenis dan diameter batang setinggi dada (DBH).

Tutupan kanopi mangrove dihitung dengan menggunakan metode hemisperichal photography dan dibutuhkan kamera yang menggunakan lensa fish eye dengan sudut pandang $180^{\circ}$ pada satu titik pengambilan foto (Korhonen et al., 2006). Teknik ini masih cukup baru digunakan di Indonesia pada hutan mangrove, penerapannya mudah dan menghasilkan data yang lebih akurat. Teknis pelaksanaannya adalah sebagai berikut:

1. Setiap plot $10 \times 10 \mathrm{~m}^{2}$ dibagi menjadi empat plot kecil yang berukuran $5 \times 5 \mathrm{~m}^{2}$.

2. Titik pengambilan foto ditempatkan di sekitar pusat plot kecil, harus berada diantara satu pohon dengan pohon lainnya, serta hindarkan pemotretan tepat disamping batang satu pohon. 
3. Dalam setiap transek atau stratifikasi, minimal dilakukan pengambilan foto sebanyak 12 titik, dimana setiap plot $10 \times 10 \mathrm{~m}^{2}$ diambil 4 titik pemotretan

4. Posisi kamera disejajarkan dengan tinggi dada peneliti atau tim pengambil foto, serta tegak lurus menghadap ke arah langit.

5. Dicatat nomor foto pada form data sheet untuk mempermudah dan mempercepat analisis data.

6. Hindarkan pengambilan foto ganda pada setiap titik untuk mencegah kebingungan dalam analisis data.

Rumus yang digunakan untuk menghitung data struktur komunitas mangrove yang diperoleh di lapangan berdasarkan rumus Bengen (2003):

1. Kerapatan Jenis (K)

$$
K(\text { ind } / \text { ha })=\frac{\text { Jumlah individu spesies }}{\text { Luas petak pengamatan }}
$$

2. Kerapatan Relatif (KR)

$$
K R=\frac{\text { Kerapatan suatu jenis }}{\text { Kerapatan total seluruh jenis }} \times 100 \%
$$

3. Frekuensi Jenis (F) $F=\frac{\text { Jumlah plot ditemukan suatu spesies }}{\text { Jumlah seluruh plot }}$

4. Frekuensi Relatif (FR)

$F R=\frac{\text { Frekuensi suatu jenis }}{\text { Frekuensi seluruh jenis }} \times 100 \%$

5. Dominansi Jenis (D)

$D\left(m^{2} / h a\right)=\frac{\text { Jumlah basal area } D B H \text { jenis } i}{\text { Luas total area pengamatan }}$

6. Dominansi Relatif (DR)

$D R=\frac{\text { Dominansi suatu jenis }}{\text { Dominansi total seluruh jenis }} \times 100 \%$

7. Basal Area (BA)

Keterangan :

$$
B A\left(\mathrm{~cm}^{2}\right)=\frac{\pi D B H^{2}}{4}
$$

$\mathrm{BA}=$ Basal Area
$\mathrm{DBH}=$ Diameter pohon mangrove setinggi dada $(\pi=3,1416)$

8. Indeks Nilai Penting (INP)

$$
I N P=K R+F R+D R
$$

\section{Keterangan:}

$\begin{array}{ll}\mathrm{INP}= & \text { Indeks Nilai Penting } \\ \mathrm{KR}= & \text { Kerapatan relatif jenis ke } i \\ \mathrm{FR}= & \text { Frekuensi relatif jenis ke } i \\ \mathrm{DR}= & \begin{array}{l}\text { Penutupan relatif } \\ \text { atau dominansi relatif jenis } \\ \text { ke } i\end{array}\end{array}$

\section{HASIL DAN PEMBAHASAN Kondisi Umum}

Dompak adalah sebuah kelurahan yang terletak di kecamatan Bukit Bestari Kota Tanjungpinang Kepulauan Riau Indonesia. Kelurahan Dompak meliputi seluruh Pulau Dompak dan wilayah Dompak Daratan. Pulau Dompak merupakan pusat pemerintahan provinsi Kepulauan Riau. Kelurahan Dompak merupakan salah satu kelurahan yang termasuk dalam wilayah kerja Kecamatan Bukit Bestari yang memiliki luas wilayah $\pm 4.280 \mathrm{Ha}$ (Kelurahan Dompak, 2018).

Kelurahan Dompak memiliki wilayah yang terdiri dari dataran tinggi $\pm 25 \%$, dataran rendah $\pm 35 \%$, pesisir pantai $\pm 10 \%$, dan laut $\pm 30 \%$. Keadaan geografis Dompak juga terdiri dari dua pulau yaitu sebagian masuk di dalam pulau Bintan $\pm 65 \%$ dan sebagian terdiri dari satu pulau yaitu pulau Dompak dengan Luas $\pm 35 \%$. Kelurahan Dompak terletak di lintang khatulistiwa yang mempunyai 2 musim, yaitu musim kemarau yang terjadi pada rentang bulan April sampai dengan September dan musim hujan yang terjadi pada rentang bulan Oktober sampai dengan Maret (Kelurahan Dompak, 2018).

\section{Parameter Lingkungan Mangrove}

Hasil pengukuran parameter perairan yang telah dilakukan adalah seperti pada Tabel 1. 
Tabel 1. Rata-rata Hasil Pengukuran Parameter Kualitas Perairan di Kelurahan Dompak

\begin{tabular}{|c|c|c|c|c|c|}
\hline No & Parameter & $\begin{array}{c}\text { Stasiun I } \\
\text { N 00 } 52^{\prime} 31^{\prime \prime} \\
\text { E 104²9'36" }\end{array}$ & $\begin{array}{c}\text { Stasiun II } \\
\text { N 0052'06" } \\
\text { E } 104^{\circ} 28^{\prime} 45^{\prime \prime}\end{array}$ & $\begin{array}{c}\text { Stasiun III } \\
\text { N 0052'05" } \\
\text { E 104²9'14" }\end{array}$ & Baku Mutu* \\
\hline 1 & Suhu $\left({ }^{\circ} \mathrm{C}\right)$ & 28,9 & 29,3 & 29 & $28-32$ \\
\hline 2 & Salinitas \%o & 29 & 29,7 & 29,1 & s/d 34 \\
\hline 3 & $\mathrm{pH}$ & 7 & 7 & 7 & $7-8,5$ \\
\hline
\end{tabular}

Berdasarkan hasil pengukuran kualitas air diperoleh nilai suhu tertinggi terdapat pada stasiun II dengan nilai $29,3^{\circ} \mathrm{C}$. Nilai salinitas tertinggi terdapat pada stasiun II dengan nilai $29,7 \%$. Nilai $\mathrm{pH}$ pada seluruh stasiun bernilai sama yakni 7.

Pengukuran suhu berkisar antara 28,9-29, $3^{\circ} \mathrm{C}$, salinitas berkisar antara 2929,7\% dan $\mathrm{pH}$ perairan bernilai 7 .

Suhu merupakan salah satu faktor yang sangat menentukan dalam proses metabolisme organisme di perairan. Menurut Schaduw (2018), suhu yang mendadak berubah atau terjadinya perubahan suhu yang ekstrim akan mengganggu kehidupan organisme atau dapat menyebabkan kematian.

Perbedaan nilai suhu yang diperoleh dari ketiga stasiun penelitian dipengaruhi oleh perbedaan waktu pengukuran, dimana waktu pengukuran erat kaitannya dengan intensitas cahaya matahari yang diserap oleh air. Kisaran suhu ini masih dalam batasan toleransi untuk kehidupan mangrove. Menurut Ulqodry et al,. (2010), suhu yang baik untuk mangrove tidak kurang dari $20^{\circ} \mathrm{C}$.

Salinitas merupakan salah satu faktor penting yang mampu mempengaruhi pertumbuhan, daya tahan dan penyebaran jenis mangrove. Hasil pengukuran salinitas yang diperoleh berkisar antara 29-29,7\% . Tumbuhan mangrove dapat tumbuh dengan baik dengan kadar salinitas 10-30 ppt (Wantasen, 2013). Nilai salinitas yang tinggi ataupun rendah dipengaruhi oleh ada tidaknya aliran air tawar yang masuk ke dalam perairan mangrove. Nilai salinitas tertinggi ditemukan di stasiun II, diduga disebabkan karena wilayah stasiun II berada lebih dekat dengan laut lepas dari pada wilayah stasiun I dan stasiun III sehingga aliran air tawar yang masuk lebih sedikit.

Derajat keasaman $(\mathrm{pH})$ adalah salah satu faktor yang dapat mempengaruhi pertumbuhan mangrove. Hal ini disebabkan karena nilai $\mathrm{pH}$ merupakan faktor penting bagi organisme karena perubahan $\mathrm{pH}$ dapat mempengaruhi fungsi fisiologis khususnya yang berhubungan dengan respirasi (Eddy et al., 2015). Nilai $\mathrm{pH}$ yang diperoleh dari ketiga stasiun bernilai 7 . Hal ini diduga disebabkan oleh kondisi perairan ketiga stasiun berada pada daerah yang sama yakni di Selat Dompak. Ulqodry et al., (2010) menyatakan bahwa nilai $\mathrm{pH}$ yang diperoleh berkisar tidak terlalu jauh diduga terjadi karena adanya kesetimbangan antara proses penguraian serasah mangrove yang cenderung menghasilkan kondisi asam dengan pengaruh kapasitas penyangga (buffer) oleh garam-garam karbonat dan bikarbonat pada air laut yang lebih bersuasana basa

Nilai rata-rata kualitas air yang diperoleh masih dapat mendukung kehidupan mangrove dikarenakan berada di atas baku mutu air laut untuk biota laut (KepMen L.H No. 51 Tahun 2004).

Hasil analisis sedimen yang telah dilakukan adalah seperti pada Tabel 2 
Tabel 2. Tipe Sedimen Pada Setiap Stasiun Penelitian di Kelurahan Dompak

\begin{tabular}{|c|c|c|c|c|}
\hline \multirow{2}{*}{ Stasiun } & \multicolumn{3}{|c|}{ Fraksi Sedimen (\%) } & \multirow{2}{*}{ Jenis Sedimen } \\
\hline & Kerikil & Pasir & Lumpur & \\
\hline I & 3 & 37,06 & 59,94 & Lumpur Berpasir \\
\hline II & 2,13 & 30,21 & 67,66 & Lumpur Berpasir \\
\hline III & 2,05 & 28,28 & 69,67 & Lumpur Berpasir \\
\hline
\end{tabular}

Berdasarkan hasil analisis tipe sedimen yang telah dilakukan di lokasi penelitian didapatkan hasil bahwa susbtrat dari ketiga stasiun penelitian adalah lumpur berpasir. Persentase fraksi kerikil tertinggi terdapat pada stasiun I dengan nilai $3 \%$ dan terendah pada stasiun II dan III dengan nilai $2 \%$. Persentase fraksi pasir tertinggi terdapat pada stasiun I dengan nilai $37,06 \%$ dan terendah terdapat pada stasiun III dengan nilai $28,28 \%$. Persentase fraksi lumpur tertinggi terdapat pada stasiun III dengan nilai $69,67 \%$ dan terendah terdapat pada stasiun I dengan nilai 59,94\%.

Fraksi lumpur tertinggi ditemukan pada stasiun III, dimana hal ini disebabkan karena tingkat kerapatan mangrove pada stasiun III merupakan yang tertinggi diantara stasiun yang lainnya serta tingkat kerapatan jenis dari famili Rhizophoraceae tertinggi ditemukan di stasiun III ini. Menurut Febriawan et al., (2014), substrat yang sesuai untuk jenis mangrove dari famili Rhizophoraceae adalah substrat lumpur berpasir. Akar-akar mangrove berfungsi sebagai perangkap (trapped) partikel tanah dan mengendapkannya, sehingga menyebabkan endapan lumpur tidak hanyut oleh arus dan gelombang.

\section{Komposisi Spesies Mangrove}

Hasil pengamatan di lapangan berdasarkan identifikasi morfologi mangrove diperoleh sebanyak 10 jenis dari 7 famili mangrove (Gambar 4).

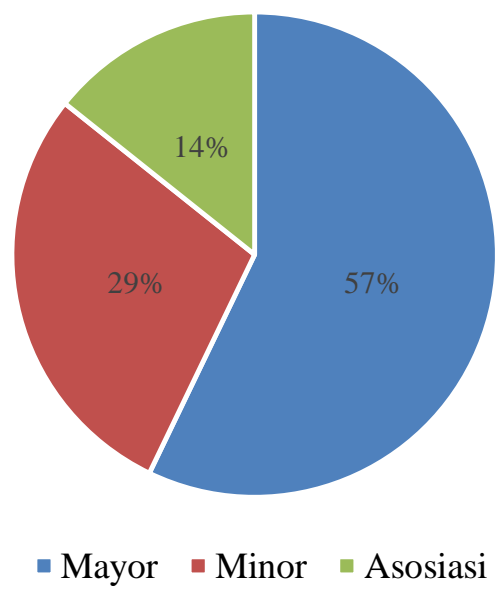

Gambar 3. Komposisi Mangrove pada ketiga Stasiun Pengamatan di Kelurahan Dompak

Komposisi mangrove pada ketiga stasiun pengamatan diperoleh tiga komponen vegetasi yaitu komponen mayor, minor dan asosiasi. Komponen mayor terdiri atas 4 famili yakni Avicenniaceae, Rhizophoraceae, Arecaceae dan
Sonneratiaceae. Komponen minor terdiri atas 2 famili yakni Meliaceae dan Rubiceae. Komponen asosiasi hanya terdapat 1 famili yakni Malvaceae.

Pada komponen mayor didominasi oleh famili Rhizophoraceae dengan 
ditemukannya 4 spesies dari famili tersebut, kemudian selanjutnya famili Avicenniaceae, Arecaceae dan Sonneratiaceae yang masing-masing ditemukan satu spesies. Komponen minor hanya ditemukan 2 famili yaitu Meliaceae dan Rubiaceae dengan masing-masing 1 spesies serta komponen asosiasi hanya ditemukan 1 famili yaitu Malvaceae dengan 1 spesies.

Komposisi mangrove yang ditemukan didominasi oleh famili Rhizophoraceae dengan dijumpainya 4 jenis mangrove. Hal ini dikarenakan substrat yang berada di lokasi penelitian adalah jenis lumpur berpasir dimana karakteristik substrat ini sangat cocok untuk pertumbuhan mangrove dari famili Rhizophoraceae.

Berdasarkan data komposisi mangrove yang diperoleh yakni 10 jenis mangrove, maka jumlah spesies mangrove di Kelurahan Dompak lebih rendah jika dibandingkan dengan jumlah spesies mangrove di daerah lain, seperti di daerah Pulau Keter Tengah Kabupaten Bintan ditemukan sebanyak 15 jenis mangrove (Syahputra et al., 2013) dan di Desa Sebong Lagoi Kabupaten Bintan ditemukan sebanyak 14 jenis mangrove (Mernisa dan Oktamersetyani, 2017). Adanya Perbedaan jumlah spesies mangrove yang ditemukan dengan daerah lain diduga disebabkan oleh pengaruh kondisi lingkungan dan aktivitas antropogenik yang berbeda-beda pada setiap wilayah penelitian.

\section{Kerapatan Mangrove}

Hasil analisis perhitungan dari kerapatan mangrove adalah seperti pada Gambar 5.

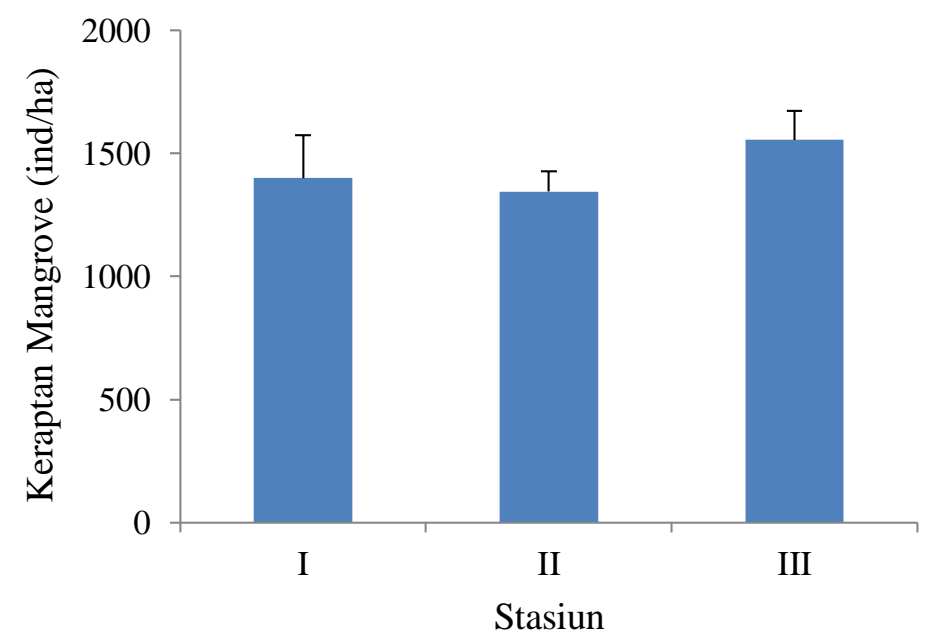

Gambar 4. Nilai Kerapatan Mangrove pada Setiap Stasiun Pengamatan di Kelurahan Dompak

Berdasarkan analisis kerapatan mangrove yang telah dilakukan, diperoleh nilai kerapatan mangrove berkisar antara $1344,44-1555,56 \quad \mathrm{ind} / \mathrm{ha} \quad$ yang menggambarkan kondisi kerapatan mangrove di Kelurahan Dompak berada dalam kondisi baik dengan kriteria sedang untuk stasiun I dan stasiun II dan kriteria padat untuk stasiun III. Nilai kerapatan tertinggi terdapat pada stasiun III dengan nilai 1555,56 ind/ha, lalu stasiun I dengan nilai $1400 \mathrm{ind} / \mathrm{ha}$ dan stasiun II dengan nilai $1344,44 \mathrm{ind} / \mathrm{ha}$. Hal ini terjadi karena wilayah penelitian stasiun III merupakan wilayah hutan mangrove yang jauh dari permukiman warga sehingga tidak terdapat pengaruh antropogenik yang besar dan membuat hutan mangrovenya masih dalam kondisi yang baik dan alami. 
Kerapatan jenis mangrove yang ditemukan pada ketiga stasiun didominasi oleh jenis $R$. apiculata. Hal ini dikarenakan substrat yang terdapat pada ketiga stasiun sama yakni lumpur berpasir dimana substrat ini merupakan habitat yang sangat sesuai untuk $R$. apiculata tumbuh dan berkembang. Ketiga stasiun juga merupakan wilayah yang selalu terkena pasang surut air laut sehingga sangat mendukung keberadaan $R$. apiculata. Hal ini sesuai dengan kajian Ghufran (2012) yang menyatakan bahwa zona Rhizopora sp. terletak pada daerah genangan pada saat pasang normal.

Nilai kerapatan mangrove yang berada di Kelurahan Dompak lebih tinggi jika dibandingkan dengan lokasi lainnya seperti di di Kawasan Konservasi Lamun Trikora Bintan Kepulauan Riau dengan nilai berkisar antara 428,54-800 ind/ha (Mulyadi et al., 2016) dan di Perairan Pesisir Kelurahan Sawang Kecamatan Kundur Barat Kabupaten Karimun dengan nilai berkisar antara 1.160-1.200 ind/ha (Kamalia et al., 2012).

\section{Tutupan Kanopi Mangrove Dengan Metode Hemispherical Photography}

Hasil perhitungan persentase tutupan kanopi mangrove menggunakan metode Hemispherical Photography adalah seperti pada Gambar 6

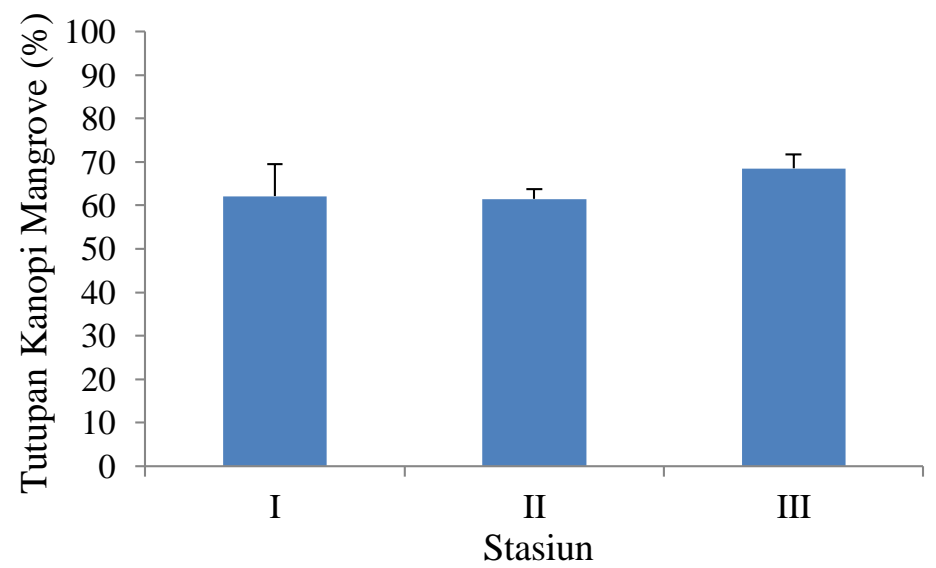

Gambar 5. Persentase Tutupan Kanopi Mangrove pada Setiap Stasiun di Kelurahan Dompak

Berdasarkan analisis persentase tutupan kanopi mangrove yang telah dilakukan, diperoleh nilai persentase tutupan kanopi mangrove berkisar antara 61,49-68,47\%. Nilai tutupan kanopi tertinggi terdapat pada stasiun III dengan nilai $68,47 \%$, kemudian stasiun I dengan nilai $62,13 \%$ dan stasiun II dengan nilai $61,49 \%$.

Nilai tutupan kanopi mangrove dipengaruhi oleh tingkat kerapatan pohon mangrove, dimana wilayah mangrove dengan tingkat kerapatan tinggi memiliki nilai tutupan kanopi mangrove yang tinggi pula. Hal ini terbukti dengan nilai tutupan kanopi tertinggi terdapat pada stasiun III dimana nilai kerapatan mangrove di stasiun III adalah yang tertinggi diantara stasiun lainnya. Hal ini juga didukung oleh kajian Nurdiansah dan Dharmawan (2018) yang menyatakan bahwa kondisi tutupan mangrove yang baik didukung oleh nilai kerapatan pohonnya. Nilai persentase yang tinggi diduga akibat kondisi lingkungan yang cocok dan sesuai dengan pertumbuhan mangrove.

Selain itu aktivitas antropogenik yang rendah, menyebabkan komunitas mangrove tumbuh lebat. Diameter pohon yang besar dengan kerapatan yang tinggi mendukung 
tutupan kanopi, sehingga memberikan pengaruh terhadap persentase penutupan mangrove (Baksir et al., 2018). Dharmawan dan Pramudji (2014) mengatakan bahwa tutupan kanopi mangrove dapat menunjukkan tingkat alami ekosistem mangrove dan mendeteksi ancaman antropogenik. Kondisi tutupan kanopi mangrove yang berada di Kelurahan Dompak secara keseluruhan berada dalam kondisi baik.

Tutupan kanopi mangrove yang berada di Kelurahan Dompak memiliki nilai persentase yang lebih rendah dibandingkan dengan nilai tutupan kanopi mangrove yang berada di daerah Pulau Kelong Kabupaten Bintan yang memiliki nilai persentase sebesar 87,96-91,31\% (Dharmawan, 2016) dan di Kampung Gisi Kabupaten Bintan Provinsi Kepulauan Riau yang memiliki nilai persentase berkisar antara 86,29-92,27\% (Rasyid et al., 2017).

\section{Indeks Nilai Penting}

Hasil dari perhitungan indeks nilai penting pada masing-masing stasiun penelitian adalah seperti pada Gambar 7

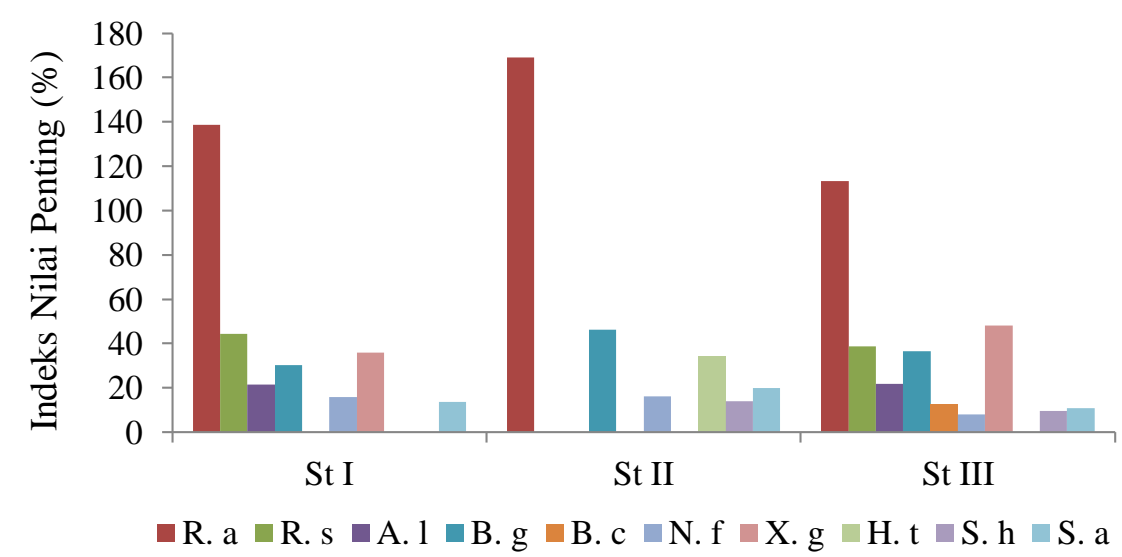

Jenis Mangrove

Gambar 6. INP Setiap Jenis pada Setiap Stasiun Pengamatan di Kelurahan Dompak

Indeks nilai penting (INP) jenis mangrove yang diperoleh berkisar antara 4,29-140,32\% dari rata-rata ketiga stasiun. Indeks nilai penting jenis mangrove yang tertinggi ditemukan pada jenis $R$. apiculata dengan nilai rata-rata $140,32 \%$ dan terendah ditemukan pada jenis $B$. cylindrica dengan nilai rata-rata $4,29 \%$. Jenis $R$. stylosa memiliki nilai rata-rata $27,70 \%, A$. lanata memiliki nilai rata-rata $14,5 \%, B$. gymnorrhiza memiliki nilai rata-rata $37,71 \%$, N. fruticans memiliki nilai ratarata $13,36 \%, X$. granatum memiliki nilai rata-rata $27,95 \%, H$. tiliaceus memiliki nilai rata-rata $11,42 \%, S$. hydrophyllacea memiliki nilai rata-rata $7,93 \%$ dan $S$. alba memiliki nilai rata-rata $14,82 \%$.
Tingginya INP dari spesies $R$. apiculata disebabkan oleh tingginya tingkat kerapatan relatif, frekuensi relatif dan dominansi relatif yang diperoleh dari ketiga stasiun. Hal ini terjadi karena daerah lokasi penelitian memiliki substrat lumpur berpasir dimana faktor ini sangat mendukung jenis mangrove Rhizophora untuk hidup dan berkembang dengan baik. Menurut Parmadi et al., (2016), tingginya INP $R$. apiculata dikarenakan kondisi substrat yang terdapat pada lokasi penelitian adalah lumpur berpasir. Kualitas jenis tanah seperti ini merupakan jenis tanah yang sesuai untuk mangrove jenis $R$. apiculata karena memiliki tingkat kesuburan tinggi, sehingga jenis $R$. apiculata dapat mendominasi di suatu 
vegetasi komunitas mangrove. Selanjutnya Indriyanto (2006) berpendapat bahwa spesies-spesies yang dominan (yang berkuasa) dalam suatu komunitas tumbuhan akan memiliki indeks nilai penting yang tinggi, sehingga spesies yang paling dominan akan memiliki indeks nilai penting yang paling besar.

Tingginya INP dari jenis Rizhophora menggambarkan bahwa hutan mangrove yang berada di Kelurahan Dompak masih dalam kondisi yang alami dan belum banyak mengalami perubahan. Hal ini sesuai dengan kajian Usman et al. (2013) yang menyatakan bahwa Jenis Rhizophora mempunyai peranan yang tinggi di lokasi penelitian karena mangrove jenis ini memiliki karakteristik dan morfologi yang mendukung dalam hal bersaing dengan jenis lainnya dan dapat dikatakan kondisi perairan di lokasi penelitian baik untuk pertumbuhan mangrove.

\section{KESIMPULAN}

Komposisi spesies mangrove yang ditemukan di Kelurahan Dompak terdiri atas 10 jenis mangrove yakni $A$. lanata, B. gymnorrhiza, B. cylindrica, $H$. Tiliaceus, $N$. fruticans, $R$. apiculata, $R$. stylosa, S. alba, S. hydrophyllacea dan X. granatum.

Kondisi hutan mangrove berdasarkan kerapatan, tutupan kanopi dan indeks nilai penting (INP) mangrove yang berada di Kelurahan Dompak Kecamatan Bukit Bestari Kota Tanjungpinang Provinsi Kepulauan Riau dalam kondisi yang baik.

\section{DAFTAR PUSTAKA}

1. Baksir, A., Mutmainnah, N. Akbar dan F. Ismail. (2018). Penilaian Kondisi Menggunakan Metode Hemispherical Photography pada Ekosistem Mangrove di Pesisir Desa Minaluli Kecamatan Mangoli Utara Kabupaten Kepulauan Sula Provinsi Maluku Utara. Jurnal Sumberdaya Akuatik Indopasifik, 2(2): 69-80.

2. Bengen, D. G. (2003). Pedoman Teknis: Pengenalan dan Pengelolaan Ekosistem Mangrove. Pusat Kajian Sumberdaya Pesisir dan Lautan IPB. Bogor.

3. Dharmawan, I. W. E dan Pramudji. (2014). Panduan Monitoring Kesehatan Ekosistem Mangrove. COREMAP-CTI, Pusat Penelitian Oseanografi, LIPI. Jakarta.

4. Dharmawan, I. W. E. (2016). Variasi Spasial Emisi Gas Rumah Kaca (GRK) pada Ekosistem Mangrove di Pulau Kelong Bintan. [Tesis]. Sekolah Pascasarjana. Universitas Institut Pertanian Bogor. Bogor

5. Febriawan, E. N., A. Pratomo dan A. Zulfikar. (2014). Jenis dan Karakteristik Sedimen di Daerah Mangrove Perairan Teluk Antang Kecamatan Siantan Kabupaten Kepulauan Anambas. Jurnal Elektronik, 1(1): 14-30.

6. Ghufran, M. (2012). Ekosistem Mangrove Potensi, Fungsi dan Pengelolaan. PT. Rineka Cipta. Jakarta.

7. Husin, Z., K. Ismail dan Susiana. (2017). Kajian Kesesuaian Wisata Mangrove Kawasan Pesisir Dompak Tanjungpinang Kepulauan Riau. Jurnal Elektronik, 1(1): 6782.

8. Indriyanto. (2006). Ekologi Hutan. PT. Bumi Aksara, Jakarta.

9. Kamalia, I. T. S. Raza dan T. Efrizal. (2012). Struktur Komunitas Hutan Mangrove di Perairan Pesisir Kelurahan Sawang Kecamatan Kundur Barat Kabupaten Karimun. Jurnal Akuatiklestari, 1(1): 30-37. 
10. Kelurahan Dompak. (2018). Laporan Tahunan Kelurahan Dompak Kecamatan Bukit Bestari Kota Tanjungpinang Tahun 2018. Tanjungpinang.

11. KLH [Kementerian Lingkungan Hidup]. (2004). Keputusan Menteri Negara Lingkungan Hidup Nomor 51 Tahun 2004. Tentang Baku Mutu Air Laut. Kementerian Lingkungan Hidup. Jakarta.

12. Korhonen, L., K. T. Korhonen, M. Rautiainen and P. Stenberg. (2006). Estimation of Forestcanopy Cover: a Comparison of Field Measurement Techniques. Silva Fennica, 40(4): 577-588.

13. Mernisa, M. dan W. Oktamarsetyani. (2017). Keanekaragaman Jenis Vegetasi Mangrove di Desa Sebong Lagoi Kabupaten Bintan. Prosiding Seminar Nasional Pendidikan Biologi dan Biologi. Fakultas Matematika dan Ilmu Pengetahuan Alam. Universitas Negeri Yogyakarta. Yogyakarta.

14. Mulyadi, A., D. Yoswaty dan I. Ilahi. (2016). Dampak Lingkungan Dari Pengembangan Ekowisata Bahari di Kawasan Konservasi Lamun Trikora, Bintan, Kepulauan Riau. Berkala Perikanan Terubuk, 45(1): 96-111.

15. Noor, Y.R., M. Khazali dan I. N. N. Suryadiputra. (2006). Panduan Pengenalan

16. Mangrove di Indonesia. Cetakan II. Wetlands International Indonesian Program. Bogor

17. Nurdiansah, D. dan I. W. E Dharmawan. (2018). Komunitas Mangrove di Wilayah Pesisir Pulau Tidore dan Sekitarnya. Jurnal Oseanologi dan Limnologi Indonesia, 3(1): $1-9$.

18. Parmadi, E. H., I. Dewiyanti dan S. Karina. (2016). Indeks Nilai Penting Vegetasi Mangrove di Kawasan Kuala Idi Kabupaten Aceh Timur. Jurnal Ilmiah Mahasiswa Kelautan dan Perikanan Unsyiah, 1(1): 82-95.

19. Rasyid, A., D. Azizah dan Susiana. (2017). Faktor-Faktor Produksi Serasah Hutan Mangrove di Kampung Gisi Kabupaten Bintan Provinsi Kepulauan Riau. Jurnal Elektronik, 1(1): 65-77.

20. Schaduw, J. N. W. (2018). Distribusi dan Karakteristik Kualitas Perairan Ekosistem Mangrove Pulau Kecil Taman Nasional Bunaken. Jurnal Majalah Geografi Indonesia, 32(1): 40-49.

21. Syahputra, R., F. Yandri dan C. J. Koenawan. (2013). Struktur Komunitas Mangrove di Pulau Keter Tengah Kabupaten Bintan. Jurnal Elektronik, 1(1): 45-51.

22. Ulqodry, T. Z., D. G. Bengen dan R. F. Kaswadji. (2010). Karakteristik Perairan Mangrove Tanjung Api-Api Sumatera Selatan Berdasarkan Sebaran Parameter Lingkungan Perairan Dengan Menggunakan Analisis Komponen Utama (PCA). Maspari Journal, 1(1): 16-21.

23. Usman, L., Syamsuddin dan S. N. Hamzah. (2013). Analisis Vegetasi Mangrove di Pulau Dudepo Kecamatan Anggrek Kabupaten Gorontalo Utara. Jurnal Ilmiah Perikanan dan Kelautan, 1(1): 11-17.

24. Wantasen, A. S. (2013). Kondisi Kualitas Perairan dan Substrat Dasar Sebagai Faktor Pendukung Aktivitas Pertumbuhan Mangrove di Pantai Pesisir Desa Basaan I Kabupaten Minahasa Tenggara. Jurnal Ilmiah Platax, 1(4): 204-209. 